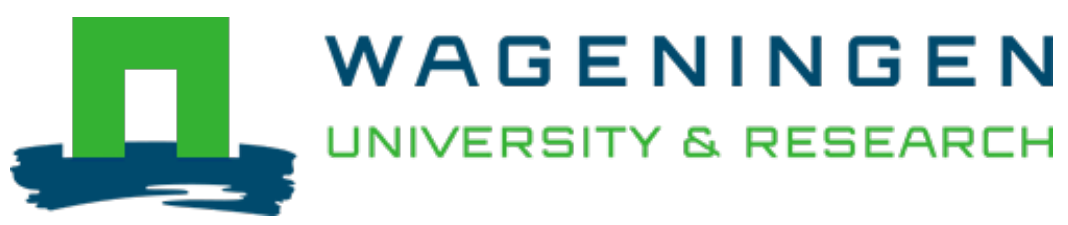

\title{
Investigation of the 2018 Shiraz dust event: Potential sources of metals, rare earth elements, and radionuclides; health assessment
}

Chemosphere

Abbasi, Sajjad; Rezaei, Mahrooz; Keshavarzi, Behnam; Mina, Monireh; Ritsema, Coen et al https://doi.org/10.1016/j.chemosphere.2021.130533

This publication is made publicly available in the institutional repository of Wageningen University and Research, under the terms of article $25 \mathrm{fa}$ of the Dutch Copyright Act, also known as the Amendment Taverne. This has been done with explicit consent by the author.

Article 25 fa states that the author of a short scientific work funded either wholly or partially by Dutch public funds is entitled to make that work publicly available for no consideration following a reasonable period of time after the work was first published, provided that clear reference is made to the source of the first publication of the work.

This publication is distributed under The Association of Universities in the Netherlands (VSNU) 'Article $25 \mathrm{fa}$ implementation' project. In this project research outputs of researchers employed by Dutch Universities that comply with the legal requirements of Article $25 \mathrm{fa}$ of the Dutch Copyright Act are distributed online and free of cost or other barriers in institutional repositories. Research outputs are distributed six months after their first online publication in the original published version and with proper attribution to the source of the original publication.

You are permitted to download and use the publication for personal purposes. All rights remain with the author(s) and / or copyright owner(s) of this work. Any use of the publication or parts of it other than authorised under article $25 \mathrm{fa}$ of the Dutch Copyright act is prohibited. Wageningen University \& Research and the author(s) of this publication shall not be held responsible or liable for any damages resulting from your (re)use of this publication.

For questions regarding the public availability of this publication please contact openscience.library@wur.nl 


\title{
Investigation of the 2018 Shiraz dust event: Potential sources of metals, rare earth elements, and radionuclides; health assessment
}

\author{
Sajjad Abbasi ${ }^{\text {a, }}$, Mahrooz Rezaei ${ }^{\text {b, c }}$, Behnam Keshavarzi ${ }^{\text {a }}$, Monireh Mina ${ }^{\text {b }}$, \\ Coen Ritsema ${ }^{\mathrm{d}}$, Violette Geissen ${ }^{\mathrm{d}}$ \\ a Department of Earth Sciences, College of Sciences, Shiraz University, Shiraz, 71454, Iran \\ ${ }^{\mathrm{b}}$ Department of Soil Science, School of Agriculture, Shiraz University, Shiraz, Iran \\ ${ }^{\mathrm{c}}$ Meteorology and Air Quality Group, Wageningen University \& Research, PO. Box 47, 6700, AA, Wageningen, the Netherlands \\ ${ }^{\mathrm{d}}$ Soil Physics and Land Management Group, Wageningen University \& Research, PO. Box 47, 6700, AA, Wageningen, the Netherlands
}

\section{H I G H L I G H T S}

- Settled dust was used to assess the Shiraz dust event (May 13th' 2018).

- The source was mainly Saudi Arabia with contributions from Iran and Iraq.

- Mo, $\mathrm{Cu}, \mathrm{Pb}, \mathrm{Zn}$, and $\mathrm{Cd}$ originated from anthropogenic sources.

- Children were more at risk than adults.

\section{A R T I C L E I N F O}

\section{Article history:}

Received 13 February 2021

Received in revised form

3 April 2021

Accepted 5 April 2021

Available online 13 April 2021

Handling Editor: Myrto Petreas

\section{Keywords:}

Dust

Source

Health

Potentially toxic elements

Rare earth elements

Radionuclides

\section{G R A P H I C A L A B S T R A C T}

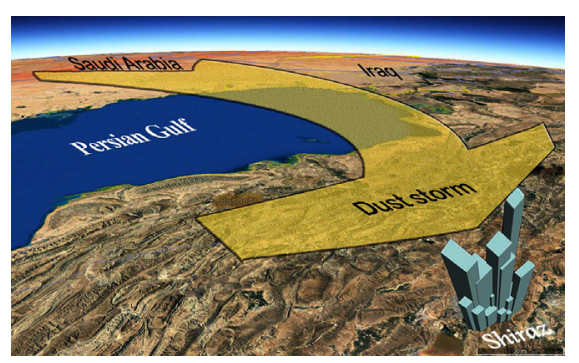

\section{A B S T R A C T}

In the middle of May 2018, an unprecedented dust storm occurred in the Shiraz metropolis. After the storm, several samples were collected from dust that settled around the city. These dust samples were analysed for potentially toxic elements (PTEs), rare earth elements (REEs), and radionuclides. This work is the first study that considered rare earth elements (REEs) for source identification and radionuclide contamination of Shiraz dust event. Hysplit model analysis and NASA and NOAA satellite maps illustrated that the air mass affecting Shiraz was moving mainly through the Saudi Arabian deserts. In addition, REE results of the dust that settled in Shiraz showed a trend similar to shale, sandstone, and especially Saudi Arabian soils. Ti/ $\mathrm{Al}(0.01), \mathrm{Fe} / \mathrm{Al}(0.92)$, and $\mathrm{Mg} / \mathrm{Al}(0.55)$ ratios and the values of $\mathrm{LaN} / \mathrm{SmN}(0.91-0.98)$, GdN/YbN (1.8-2), LaN/YbN (1.7-1.9), HREE/LREE (0.52-0.6), Ce/Ce* (1.09-1.13), Eu/Eu* (1.03-1.18), Pr/ Pr* (0.85-0.87), Gd/Gd* (1.1-1.15), and MREEs/MREE* (4.3-4.5) ratios provided insights into dust sources. These values indicated that Shiraz dust was affected by Asaluyeh and Iraq soils during transport and the main source of the dust that settled in Shiraz on the May 13, 2018 was Saudi Arabian soil. The concentrations of $\mathrm{Mo}, \mathrm{Cu}, \mathrm{Pb}, \mathrm{Zn}, \mathrm{Ni}, \mathrm{Co}, \mathrm{Mn}, \mathrm{As}, \mathrm{Cd}, \mathrm{Ti}, \mathrm{Al}, \mathrm{Sc}$, and $\mathrm{Fe}$ in the settled dust were 0.24, 47.67, $67.33,244,70.27,19.33,664,8.39,0.65,537.33,40933.33,11.54$, and $37800 \mathrm{mg} / \mathrm{kg}$, respectively. According to the enrichment factor (EF), coefficient variation, and Positive Matrix Factorization (PMF) model the $\mathrm{Mo}, \mathrm{Cu}, \mathrm{Pb}, \mathrm{Zn}$, and $\mathrm{Cd}$ mainly originated from exhaust emissions and industrial activities. The activity concentrations of the radionuclides ${ }^{7} \mathrm{Be},{ }^{4} \mathrm{~K},{ }^{137} \mathrm{Cs}$, and ${ }^{235} \mathrm{U}$ in the Shiraz-settled dust were $814,421,14$, and $5.4 \mathrm{~Bq} \mathrm{~kg}^{-1}$, respectively and the activity concentration of ${ }^{4} \mathrm{~K}$ was higher than the crustal average. Health risk assessment indices for the elements considering all three pathways revealed the following trend: dermal contact $\left(\mathrm{HQ}_{\mathrm{derm}}\right)<$ inhalation $\left(\mathrm{HQ}_{\mathrm{inh}}\right)<$ ingestion $\left(\mathrm{HQ}_{\mathrm{ing}}\right)$. The values of $\mathrm{HQ}_{\mathrm{inh}}$ and $\mathrm{HQ}_{\text {ing }}$ for

\footnotetext{
* Corresponding author. Department of Earth Sciences, College of Science, Shiraz University, 71454, Shiraz, Iran.

E-mail address: sajjad.abbasi@shirazu.ac.ir (S. Abbasi).
} 
children were higher than adults, while the values for the skin adsorption pathway for adults were higher than for children.

\section{Introduction}

In the earth sciences field, dust usually refers to solid inorganic particles, like mineral aerosols or soil dust, created directly from the upper continental crust by wind or human activities that cause the particles to be released into the air (Gill et al., 2006). Some regions in particular are major contributors to global atmospheric dust. These regions include the Sahara Desert (Zhao et al., 2018), the Chinese Loess Plateau (Chen et al., 2007; Li et al., 2018), and the American Loess deposits (Yang et al., 2017). In addition, exhaust emissions from traffic represent a considerable source of air-borne particles in urban areas (Schauer et al., 2006). With regards to Iran, local sources together with sources from neighbouring countries all contribute to airborne dust (Abbasi et al., 2020). Airborne dust is transported from the deserts of Saudi Arabia, Iraq, Syria, and Kuwait and settle in Iran (Givehchi et al., 2013; Goudie, 2014). Dust particles affect air chemistry and climate processes, geomorphology and soil characteristics, as well as nutrient dynamics and biogeochemical cycling in both terrestrial and oceanic environments (Goudie and Middleton, 2006; Shao et al., 2011). In addition, dust particles may seriously affect human health due to its physicochemical characteristics. Physical (size, shape and dust mass concentration) and chemical (inherent and chemical adsorption) properties of dust particles are considered critical factors affecting health and safety (Meyer et al, 1996). It is worth mentioning that small dust particles are more important in themes of the primary concerns like human health. The chances of $\mathrm{PM}_{2.5}$ being transported into and deposited in deeper human lung areas are higher, and of $\mathrm{PM}_{10}$ being deposited in the upper airways. Particles on the surface of the lung can damage the tissue and cause pulmonary inflammation (Janssen et al., 2011).

Long-term exposure to dust particles contaminated with potentially toxic elements (PTEs) may pose human health risks, such as lung cancer (Verougstraete et al., 2003). For instance, Pb, $\mathrm{Hg}, \mathrm{Cd}, \mathrm{Co}, \mathrm{Ni}, \mathrm{Cu}, \mathrm{Zn}$, and As in excessive concentrations can be dangerous for human health. In addition to PTEs, radionuclides in airborne dust have recently been investigated. Anthropogenic (Igarashi et al., 2009) and natural radionuclides in dust particles can reach hazardous radiological levels (Selvasekarapandian et al., 1999). Radionuclide exposure at high concentrations can affect the body cells and it can eventually lead to cancer. Early signs of serious exposure include skin injury, cataracts, and, in the worstcase scenario, death (Taskin et al., 2009). Analysing the abundance and composition of these dust particles is important not only for determining public dose levels and health hazards but also for maintaining reference-data records to track potential future changes in human-induced environmental radioactivity with respect to nuclear activities (Tufail et al., 2006).

Iran is constantly exposed to dust storm and almost every dust storm is investigated by researchers (Ahmady-Birgani et al., 2015; Hojati et al., 2012; Hui et al., 2015; Moaref et al., 2014; Najafi et al., 2013; Rashki et al., 2011, 2012, 2013; Stone, 2015; Vishkaee et al., 2012; Zoljoodi et al., 2013). However, limited information is available regarding the May 13, 2018 Shiraz dust event, especially in terms of rare earth elements and radionuclides. In the middle of May 2018, an unprecedented dust storm occurred in the Shiraz metropolis that led to school closures and city-wide shutdowns.
This work is the first study that considered rare earth elements (REEs) for source identification and radionuclide contamination of Shiraz dust event. The main purposes of the current study were (i) to identify possible sources of the dust that settled in Shiraz by examining REEs, analysing air parcel back trajectories (Hysplit model) as well as NASA and NOAA satellite maps; (ii) to determine the distribution and relative contamination levels of PTEs in settled dust; (iii) to measure the radionuclide levels in the settled dust; (iv) to identify possible sources and contributions of PTEs using positive matrix factorization (PMF); and finally (v) to assess the human health effects and ecological risks of the settled dust. To achieve these goals, sampling stations were selected to cover the study area, and many statistical and geochemical methods were used.

\section{Materials and methods}

\subsection{Study area}

The current study was performed in the Shiraz metropolis which is located in the centre of the Fars province at $29^{\circ} 33^{\prime}$ to $29^{\circ} 41^{\prime}$ latitude and $52^{\circ} 29^{\prime}$ to $52^{\circ} 36$ longitude. 1.5 million people live in an area of roughly 240 square kilometers. Shiraz city is built on a green plain at the foot of the Zagros Mountains, $1500 \mathrm{~m}$ above sea level. It has a mild climate with an average annual rainfall of $337 \mathrm{~mm}$ and an average temperature of $16.8^{\circ} \mathrm{C}$. Shiraz is situated on a seasonal river in South-West Iran. As one of Persia's oldest cities, Shiraz has been a centre of international trade for more than a thousand years.

\subsection{Sampling and experimental setup}

On May 13th' 2018, a strong dust event occurred in Shiraz which carried dust from the southwest border of Iran. Settled dust samples were collected from 15 points within Shiraz city after the dust storm (Fig. 1). Dust samples were gently gathered from the surface of car windows (without disturbing metal or paint) and stored in polyethylene bags. The dust samples were collected directly from the top layer of settled dust such that the samples of dust were not mixed with underlying sediments. Street dust samples were not included in the current research since these samples could have been contaminated with soil from the uppermost soil surface layer.

The total concentration of potentially toxic elements (PTEs) and rare earth elements (REEs) in settled dust samples were measured using inductively coupled plasma mass spectrometry (ICP-MS) in the laboratory of Wageningen University, the Netherlands. Based on adapted Qi and Gregoire (2000) procedures, PTEs were analysed and analytical duplicates, reagent blanks, and analysis of the standard reference material were used for quality control (QC) and quality assessment (QA). In addition, a gamma-ray spectrometry set-up was used following a procedure method of ECS500 without LIMS. The peak locate threshold, peak locate range (in channels), peak area range (in channels), and identification energy tolerance of the DSALX-GA detector were 3, 1-16384, 1-16384, and $2.000 \mathrm{keV}$, respectively. The samples were analysed at Wageningen Food Safety Research, Wageningen University and Research. 


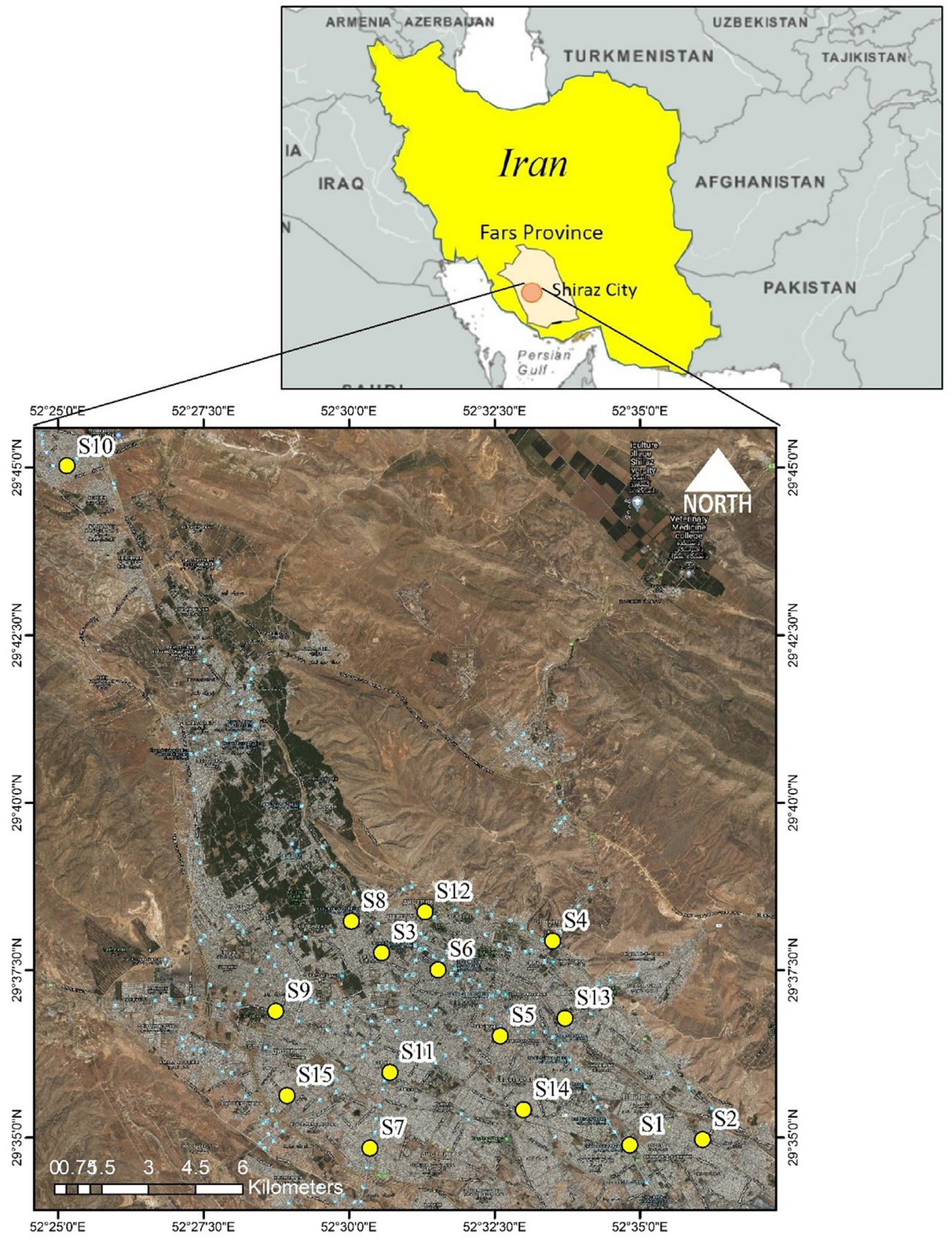

Fig. 1. Shiraz city located in Iran country and sampling points.

\subsection{Pollution assessment methods}

\subsubsection{Enrichment factor $(E F)$}

The enrichment factor (EF) in environmental analysis is one of the most important geochemical indices for assessing the degree of contamination of PTEs as well as evaluating the natural and anthropogenic origin of the elements in dust samples. The EF of each element was determined using the following equation:

$\mathrm{EF}=\frac{\left(\frac{C_{n}}{C_{\text {ref }}}\right)_{\text {sample }}}{\left(\frac{C_{n}}{C_{\text {ref }}}\right)_{\text {background }}}$

where $C_{n}$ and $C_{\text {ref }}$ are the concentrations of the target element and the reference element for the sample as well as the background (world-soil). In this study, the element Scandium (Sc) was selected as the baseline element. Scandium was used as a reference element because of its low variation coefficient and its immobility. Pollution levels were divided into five categories according to the EF values as shown in Table S1 (Lu et al., 2009).

\subsubsection{Pollution load index}

The pollution load index (PLI) gives an idea of the total pollution load at all the sites from the sum of all the PTEs. The PLI for a single site was determined using the pollution factors (CFs) for that site following the equation:

$$
P L I=\sqrt[n]{C F 1 * C F 2 * C F 3 * \ldots * C F n}
$$

The $\mathrm{CF}$ is a measurement used for determining the ratio of 
contamination of any metal in settled dust and is derived following equation (3):

$C_{f}^{i}=\frac{C_{0}^{i}}{C_{n}^{i}}$

In the equation, $C_{0}^{i}$ is the concentration of the target element in the samples and $C_{n}^{i}$ is the background concentration of an element in the earth's crust (or world-soil average). Table S1 shows the classification of CF introduced by Hakanson)1980 (. The PLI for the studied PTEs is also listed in Table S1 (Gope et al., 2017).

\subsubsection{Potential ecological risk index (RI)}

Another tool for determining the degree of contamination from PTEs is the possible ecological risk index (RI), which can be measured based on an element's toxicity and the environmental response. RI can be determined with the following equation (4) (Hakanson, 1980):

$\mathrm{RI}=\sum_{i=1}^{n} \operatorname{Er}_{i}=\sum_{i=1}^{n} \mathrm{~T}_{i} C_{f}^{i}=\sum_{i=1}^{n} \mathrm{~T}_{i} \frac{C_{s}^{i}}{B_{b}^{i}}$

Where $C_{s}^{i}$ and $B_{b}^{i}$ represent the PTE content in the settled dust and in the background, respectively. $C_{\mathrm{f}}^{\mathrm{i}}$ is the pollution factor of the PTEs. $E r_{i}$ is the potential risk factor of a single element. $T_{i}$ denotes the toxic-response factor for a given substance $(\mathrm{Cd}=30$; $\mathrm{As}=10$; $\mathrm{Pb}=\mathrm{Cu}=\mathrm{Co}=\mathrm{Ni}=5 ; \mathrm{V}=2 ; \mathrm{Zn}=\mathrm{Mn}=1$ ) (Table $\mathrm{S} 1$ ) (Hakanson, 1980).

\subsection{Health risk assessment model}

US Environmental Protection Agency (USEPA, 1996) created a model which used the Hazard Quotient (HQ) and Hazard Index (HI) for calculating the exposure of children and adults to elements in settled dust. In the model, the three main routes of exposure include inhalation, ingestion, and dermal contact. There are also many effective factors that are considered in this model and include Ingestion rate (IngR), Inhalation rate (InhR), Exposure Frequency (EF), Exposure Duration (ED), skin area (SA), Skin adherence factor (SL), Dermal absorption factor (ABS), Dermal absorption factor (ABS) for As, Particle emission factor (PEF), Average body weight (BW), Averaging contact time (AT), and Averaging contact time (AT) for carcinogenic effects (USEPA, 1989; 1996). For more details about the equations and abbreviations, readers can refer to the supplementary information found in Table S2 and Table S3.

\subsection{Statistical analysis and PMF modeling}

The statistical application program SPSS v19 was also used to conduct statistical analysis of the data such as the normality test and statistical descriptions. The positive matrix factorization (PMF) model was used as a type of multivariate factor analysis method to better classify the sources of PTEs. More information on the concepts and the use of PMF can be found in the software's user guide (the current edition of PMF as provided by the EPA PMF v5.0.14) as well as our previous study (Abbasi and Keshavarzi, 2019). In the current study, some factors were considered as anthropogenic and others as a geogenic indicator. Based on IMPROVE program, unmeasured mass (UnM) can be considered as an indicator (Malm and Hand, 2007). In fact, UnM values show the compounds which were not measured ( such as $\mathrm{Cl}^{-}$) in a study and we try to calculate it as a sea salt indicator. UnM is calculated by subtracting the reconstructed mass, which is based on our knowledge of the particle under study. Many formulas can be considered for reconstructed mass depending on the research purpose. In this study, the following formulas were considered for Shiraz passive dust as reconstructed mass:

Passive dust particles $=$ Soil + Sea Salt + Anthropogenic particles[5]

Soil $=2.2[\mathrm{Al}]+2.49[\mathrm{Al} / 0.39]+1.94[\mathrm{Ti}]+2.42[\mathrm{Fe}]+40 / 24[\mathrm{Mg}]$ [6]

Sea Salt $=1.8\left[\mathrm{Cl}^{-}\right]=\mathrm{UnM}$

Trace Elements $=\mathrm{As}+\mathrm{Cd}+\mathrm{Co}+\mathrm{Cu}+\mathrm{Mo}+\mathrm{Pb}+\mathrm{Zn}$

It is assumed that the soil grains are mainly composed of oxides of $\mathrm{Si}, \mathrm{Ca}, \mathrm{Al}, \mathrm{Si}, \mathrm{Ti}, \mathrm{Mg}$, and $\mathrm{Fe}$, with other trace elements (Malm et al., 1994). Note that equal proportions of $\mathrm{FeO}$ and $\mathrm{Fe}_{2} \mathrm{O}_{3}$ (the two common oxides of iron) should be considered (Begum et al., 2006). It should be noted that $\mathrm{Si}$ is calculated from the $\mathrm{Al} / \mathrm{Si}$ ratio in Saudi Arabia, where the source of dust originates (Alghamdi et al., 2015). The trace elements, sea salt and reconstructed soil are related to anthropogenic, marine and geogenic sources, respectively. Also in the model, REEs and element of $\mathrm{Zr}$ were used as a geogenic indicator.

The uncertainty was measured using Polissar et al. method (1998). The number of factors was based on a combined approach proposed by Brown et al. (2015) and Li et al. (2019) and the relative values of $Q_{\text {robust }}$ and $Q_{\text {theortical }}$ scaled residual distributions and the physical/chemical understanding of the dust particles. A displacement analysis (DISP) examined rotational ambiguities and a bootstrap (BS) analysis examined the measurement errors (Paatero et al., 2014). Paatero and Tapper (1993) and Reff et al. (2007) have a comprehensive mathematical description for PMF modeling and readers can refer to these papers for more information.

\subsection{HYSPLIT modeling}

In order to identify the pathway of the trajectory of this specific dust storm, version 4 of the online Hybrid Single-Particle Lagrangian Integrated Trajectory (HYSPLIT) was applied. 8-day back-trajectories (May 8, 2018 to May 15, 2018) calculated with the Hysplit model for source identification of the settled dust on 100 and $500 \mathrm{~m}$ above ground level (AGL). Paths were calculated on the basis of the GFS weather results $\left(0.25^{\circ}\right.$, global, 2019 up to the present with starting heights of $500 \mathrm{~m}$ above AGL, and the duration from May 5 to 14,2018$)$.

\section{Results and discussion}

\subsection{Dust source identification}

\subsubsection{Hysplit model and satellite maps}

Dust storms are common throughout the year over the Persian Gulf and the Arabian Peninsula. Typically, the dust storms occur in early summer and late spring. Shamal winds (strong northwesterly winds) funnel dust particles from Iraq and Turkey south into the Persian Gulf. For central Iran, this occurs from May to July when precipitation is low (Middleton, 1986). The strong Shamal winds may last for many days and often exceed the strength of the gale force.

In the present study, the source identification of dust particles was conducted according to REEs, main elements, satellite maps, and the Hysplit model. Throughout the study, backward trajectory simulations were conducted for May 2018 to determine the source of dust events and the direction of movement over the region. Fig. 2 and Fig. S1 show the Shiraz backward modeling plots for three 
NOAA HYSPLIT MODEL

Backward trajectories ending at 0700 UTC 13 May 18

GDAS Meteorological Data

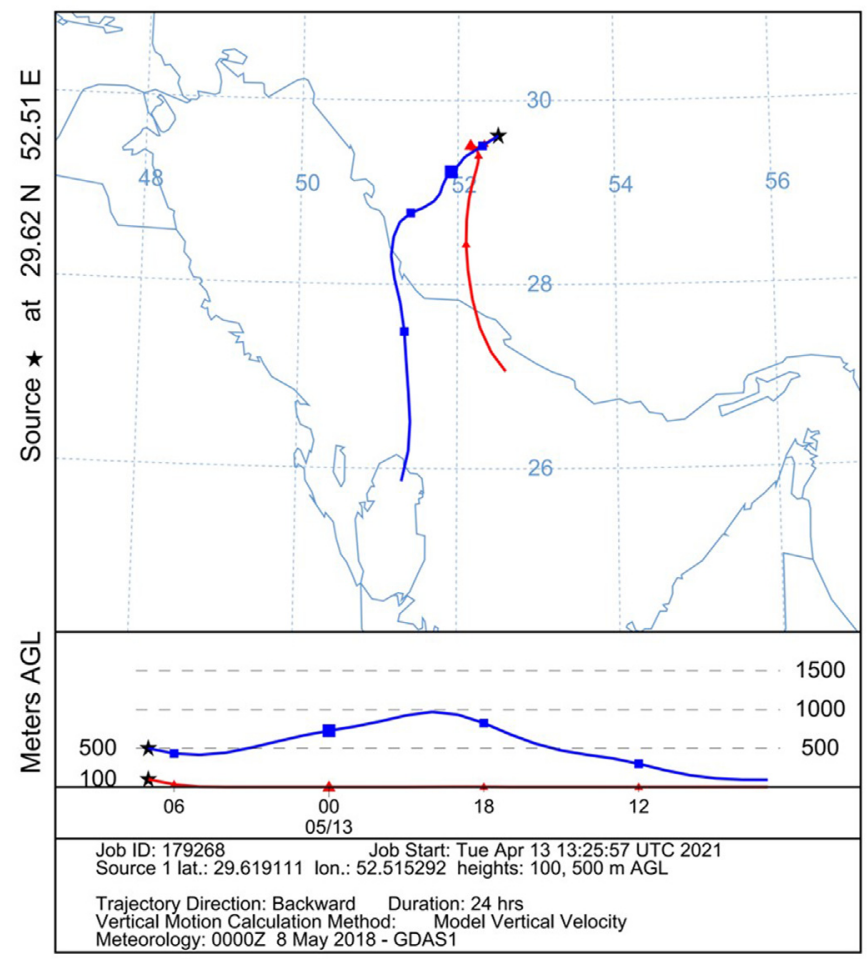

Fig. 2. Back-trajectories from May 13, 2018 calculated with the Hysplit model for source identification of settled dust at 100 and $500 \mathrm{~m} \mathrm{AGL}$.

receptor points at 500,1500, and $3000 \mathrm{~m}$ (at 0600 UTC on May 8 , 2018 to 0600 UTC on May 15, 2018). The air mass affecting Shiraz was moving mainly through the eastern desert of Iraq, Kuwait, Saudi Arabia, and the Khuzestan Province (in Iran). According to the Hysplit results, Saudi Arabia had the largest effect on the dust that settled in Shiraz (Fig. 2). The National Oceanic and Atmospheric Administration (NOAA) and the National Aeronautics and Space Administration (NASA) confirmed satellite images (Fig. 3). The NOAA satellite tool provided the image of a large dust storm over the Persian Gulf on May 13, 2018, which indicates the movement of dust from Saudi Arabia towards Iran.

\subsubsection{Main element ratios}

Elemental mass ratios of the Shiraz dust samples were compared with the potential dust sources in the Middle East and some areas inside and outside Iran (Table 1 ). The average Ti/Al ratio of 0.01 of the Shiraz dust was close to the composition of the soils found in Asaluyeh and Bushehr areas in Iran. The similarity was repeated in many other places in Iran and dust events, such as Iran the middle east springtime dust storm in 2011. As well as this ratio is similar to Saudi Arabia, UAE, Iraq, and Kuwait soils. Significant differences were observed between the soils from the Shiraz samples and soils from Djibouti. The Fe/Al ratio of the current study samples (0.92) indicates a similar relationship with soils from Qatar, Iraq, UAE, Afghanistan, and Kuwait. The observed differences between the Shiraz settled dust and the Saudi Arabian soils are attributed to the greater abundance of minerals like quartz in the coarser sieved soil samples, and fewer minerals in the finer total suspended particle (TSP) fractions. The Shiraz dust particles from May 2018 were very fine and there were fewer quartz particles, which is typical of sandy storms. The estimated crystallite size of separated particles was between 30 and $55 \mathrm{~nm}$ for quartz and between 10 and $20 \mathrm{~nm}$ for calcite (Al-Shakry et al., 2010), since the quartz hardness is higher than calcite. It is worth mentioning that calcite and carbonate minerals are dominant in southern Iran (Abbasi et al., 2017, 2018). Differences can also be ascribed to the high amount of Al-bearing minerals in the settled samples from the current study, such as clays. The settled dust particle size can be reflective of the distance, frequency, timing of precipitation events as well as the size distribution of particles in the source region (Singer et al., 2003; McTainsh et al., 1997). Therefore, the longdistance transport of dust resulted in a decrease in the size of dust particles that settled in Shiraz (Fig. 3) and the small size of particles greatly affects particle uptake through the human respiratory system. For example, the size of dust particles can affect the oxidative potential (Abbasi et al., 2020; Godri et al., 2010) and with decreasing dust particle size, penetration and deposition of particles in the human respiratory tract can be expected to increase (WHO, 1999).

Regarding the $\mathrm{Mg} / \mathrm{Al}$ ratio, it can be concluded that the ophiolitic belt in southern Iran (Kermanshah to Neiriz ophiolitic belt) causes an increase in the $\mathrm{Ni}$ and $\mathrm{Mg}$ concentrations in background soils. Thus, the $\mathrm{Mg} / \mathrm{Al}$ ratio in Iran is higher than in other places (Table 1). The $\mathrm{Mg} / \mathrm{Al}$ ratio of dust in Shiraz was lower than Bushehr and Asaluyeh in Iran (Abbasi et al., 2020; Abbasi et al., 2018; Abbasi et al., 2017). This $\mathrm{Mg} / \mathrm{Al}$ ratio revealed that the dust that settled in Shiraz originated from other places such as Saudi Arabia. The $\mathrm{Mg} / \mathrm{Al}$ ratio in the current study was close to values found in Saudi Arabia and was caused by the high abundance of palygorskite in the soils of the Eastern Arabian Peninsula (Shadfan et al., 1985) (Table 1). This result is also confirmed by back-trajectory analyses and satellite images (Fig. 3). Also, according to the PMF model (in the future sections), $\mathrm{Mg}$ element may be added to the dust particles when they passed from the Persian Gulf. Eventually, elemental ratios in the current study are similar to the soil of Iran and neighbouring countries, because of their similar geochemistry characteristic.

\subsubsection{Rare earth elements (REEs)}

The REE patterns that were normalized to upper continental crust (UCC) concentrations may help to distinguish between transported and local dust (Abbasi et al., 2020). REE concentrations were determined for Shiraz dust and then compared to other studies conducted in Iran, Iraq, and Saudi Arabia (Fig. 4). REE results of the Shiraz dust followed a similar trend of shale, sandstone, and Saudi Arabian soils as seen in these previous studies. A comparison of the results illustrated that the main source of the dust that settled in Shiraz on the May 13, 2018 originated from Saudi Arabia (Fig. 4).

The UCC-normalized data showed that dust REE patterns were very similar from site to site, with each site showing the same REE pattern. These results imply that dust sources for different sites were similar. This is reasonable because the settled dust in Shiraz originated from one source. In Shiraz-settled dust, light REEs (LREEs, $<1$ ) were usually more abundant than heavy REEs (HREEs, $>1$ ), as was also the case in parent crustal materials (Tyler, 2004). An abundance of LREEs was also observed in all the settled dust samples in this study. The HREE/LREE values of the settled dust in Shiraz were very similar for each station and varied from 0.52 to 0.6. The average HREE/LREE values of all Shiraz dust samples were close to soils in Asaluyeh (Iran), Iraq and Saudi Arabia. Thus, the dust deposited in Shiraz city was likely influenced by a storm in Saudi Arabia as well as by resuspended street dust.

Obvious variations of Eu occurred in all dust samples, and values of $\mathrm{Ce} / \mathrm{Ce}^{*}$ ranged from 1.09 to 1.13 . In dry climatic conditions, the atmosphere is oxidizing and weakly alkaline. Ce can be easily 

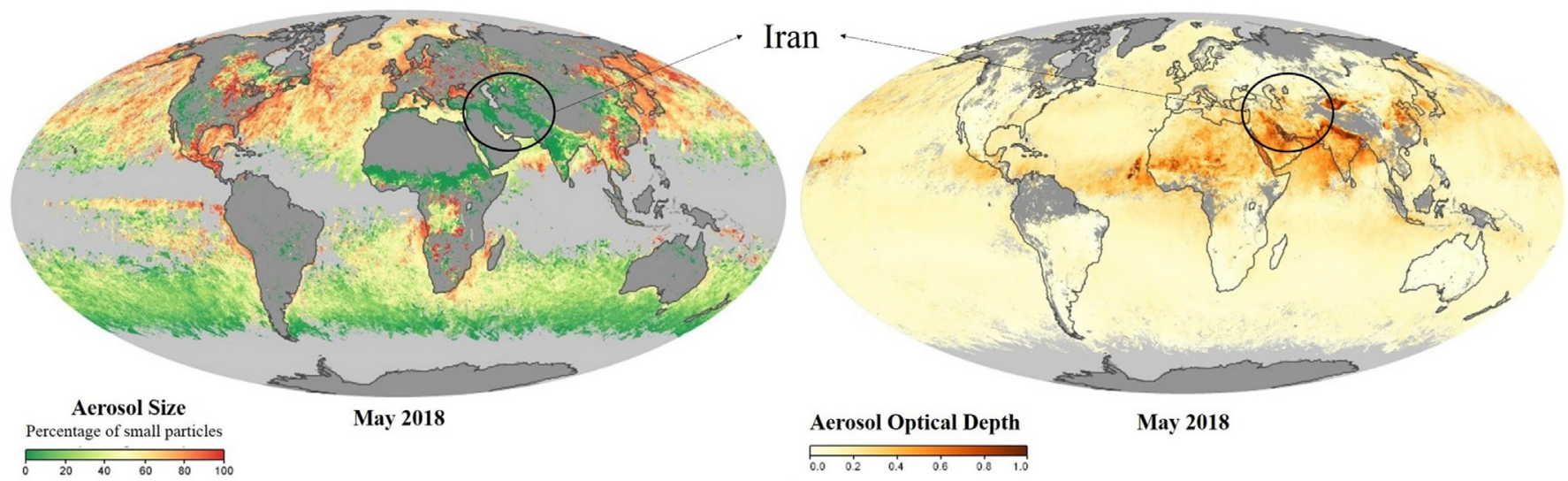

May 2018

Aerosol Optical Depth

May 2018
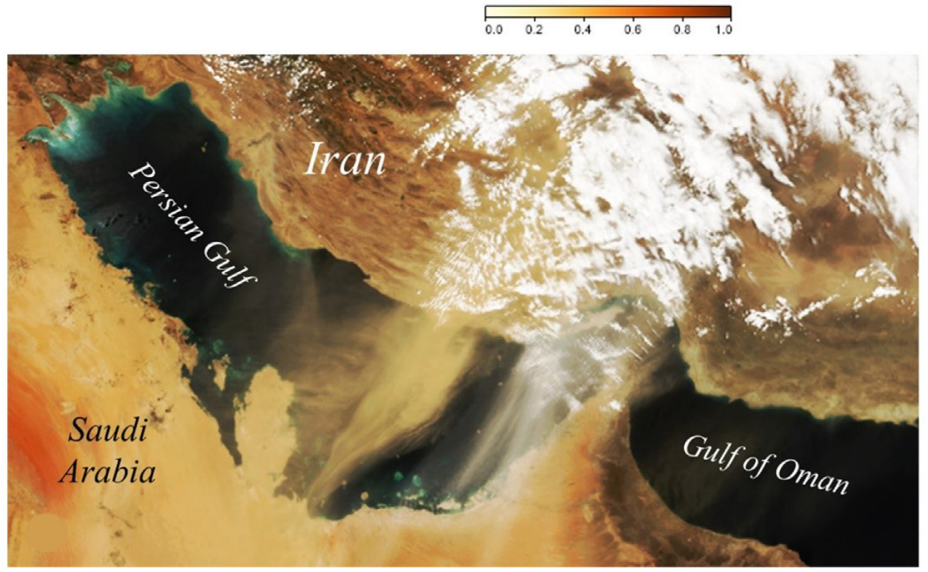

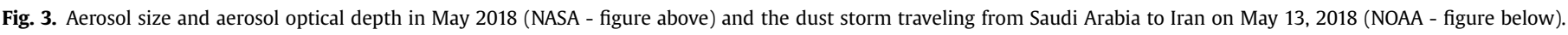

Table 1

Main element ratios for the samples of this study as compared to those of dust and soils (grab samples) from neighbouring countries (Engelbrecht et al., 2009a, 2009b, 2017; Abbasi et al., 2017, 2020; Jish Prakash et al., 2016; Ahmady-Birgani et al., 2018; Hojati et al., 2011; Najafi et al., 2013).

\begin{tabular}{|c|c|c|c|c|}
\hline Regions & Type of dust & $\mathrm{Ti} / \mathrm{Al}$ & $\mathrm{Fe} / \mathrm{Al}$ & $\mathrm{Mg} / \mathrm{Al}$ \\
\hline Iran (Shiraz) & Settled dust & 0.01 & 0.92 & 0.55 \\
\hline \multirow[t]{4}{*}{ Iran (Asaluyeh) } & Background Soil & 0.02 & 1.43 & 1.4 \\
\hline & Air borne dust (TSP) & 0.06 & 0.83 & 0.76 \\
\hline & Settled dust & 0.03 & 2.35 & 2.26 \\
\hline & Street dust & 0.03 & 2.89 & 3.56 \\
\hline Iran (Bushehr) & Street dust & 0.04 & 3.08 & 2.66 \\
\hline Iran (Middle East Springtime Dust Storm, 2011) & TSP & 0.06 & 0.52 & 0.50 \\
\hline Iran (Abadan) & $\mathrm{PM}_{10}$ & 0.02 & 0.78 & 0.88 \\
\hline Iran (Isfahan-July 2009) & Settled dust & 0.13 & 0.62 & 0.47 \\
\hline Frisbee & Settled dust & 0.14 & 1.47 & 0.11 \\
\hline Saudi Arabia soils & Street dust & 0.44 & 2.52 & 0.65 \\
\hline Djibouti & Surface soils & 0.61 & 2.53 & 0.58 \\
\hline Afghanistan & Surface soils & 0.07 & 0.71 & 0.64 \\
\hline Qatar & Surface soils & 0.18 & 0.68 & 0.71 \\
\hline UAE & Surface soils & 0.06 & 0.49 & 1.38 \\
\hline Iraq & Surface soils & 0.05 & 0.57 & 2.98 \\
\hline Kuwait & Surface soils & 0.04 & 0.42 & 0.36 \\
\hline
\end{tabular}

transported by surface weathering processes under these conditions. Several experiments have shown that weathering processes have no major effect on the values of $\mathrm{Eu} / \mathrm{Eu}^{*}$ and that Eu variations are more likely to be inherited from source materials (Prego et al., 2009). Thus, discordant Eu/Eu* anomalies at various sites indicate provenances from separate and local sources. Eu-anomaly values also do not differ from site to site (1.03-1.18) and indicate slightly more positive $\mathrm{Eu}$ anomalies than values elsewhere (except for Sandstone). Similar results were also observed in Beijing of China (Tang et al., 2013; Yang et al., 2007).

The values of the $\mathrm{LaN} / \mathrm{SmN}, \mathrm{GdN} / \mathrm{YbN}$, and $\mathrm{LaN} / \mathrm{YbN}$ ratios provide insights into REE fractionation patterns. Shiraz dust samples collected at different sites showed similar LaN/SmN, GdN/YbN, and $\mathrm{LaN} / \mathrm{YbN}$ values. This indicates that Shiraz dust originated from one source. The $\mathrm{LaN} / \mathrm{YbN}$ values of dust samples varied from 1.7 to 1.89 , and most dust samples showed distinct disparities on a LaN/ YbN versus LaN plot (Fig. 5). This illustrates that the Shiraz dust samples underwent similar weathering processes and had the same origin. Dust REE fractionation patterns at all sites were far from those from the other places (Fig. 5). In a LaN/SmN versus GdN/ YbN plot (Fig. 5), the REE fractionation patterns were close to the values found in Iraq and sandstone and the $\mathrm{LaN} / \mathrm{SmN}$ ratio was 


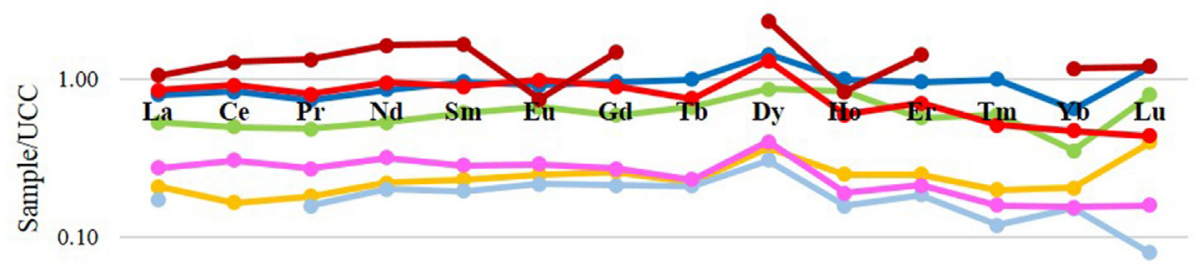

0.01

$\begin{array}{ll}\leadsto \text { Shale } & \rightarrow \text { Sandstone } \\ \approx \text { Limestone } & \rightarrow \text { Barren Soil (Iran-Asaluyeh) }\end{array}$

Fig. 4. Average of UCC-normalized REE diagram of Shiraz dust and other reference material patterns (Abbasi et al., 2020 (Iran); Jackson and Douch, 1986 (Saudi Arabia); Tobia, 2018 (Iraq)).
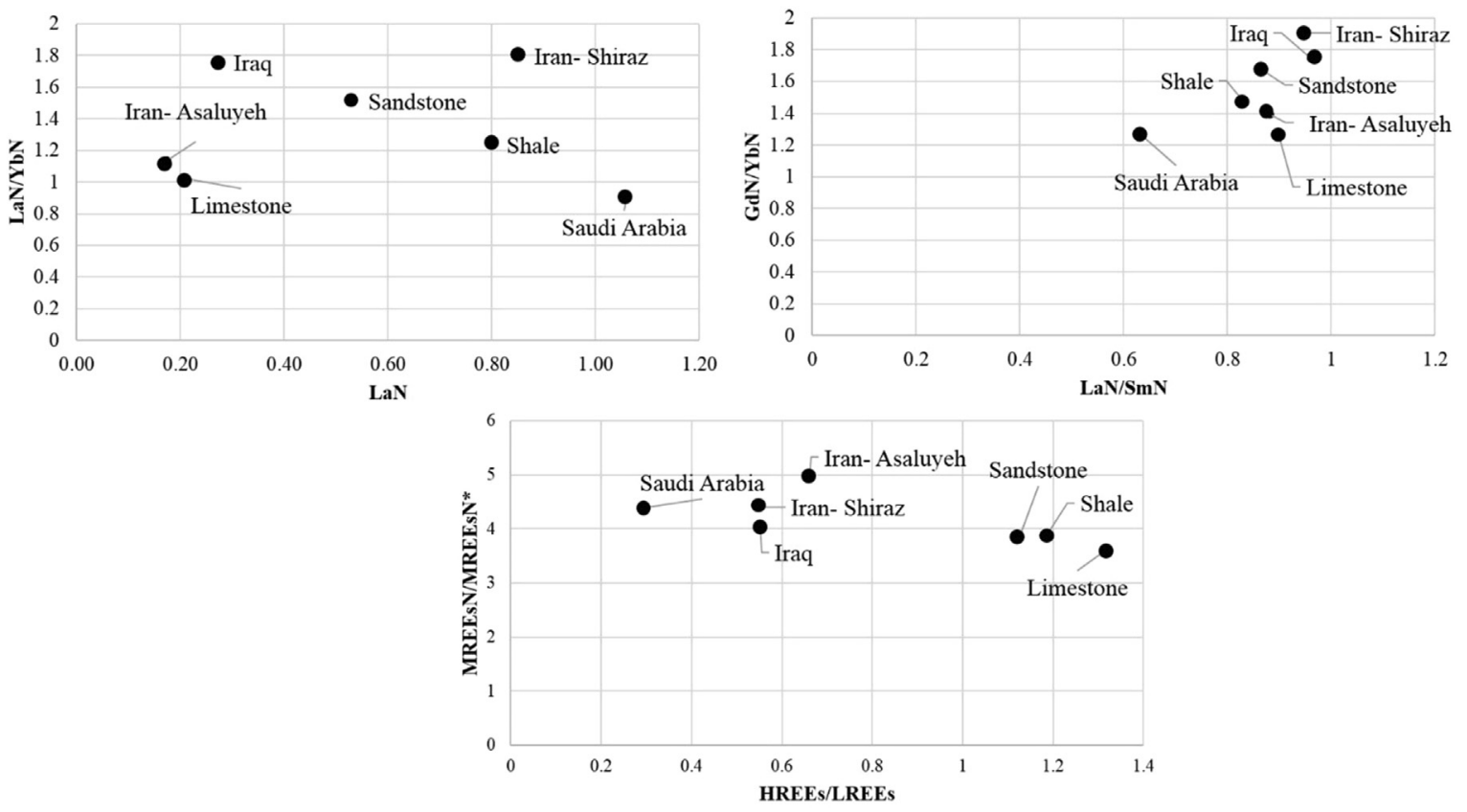

Fig. 5. LaN/YbN versus LaN, GdN/YbN versus LaN/SmN and MREEsN/MREEsN* versus HREEs/LREEs diagrams for Shiraz dust and other reference material.

close to that of Asaluyeh soil. These values indicate that the dust that settled in Shiraz was affected by Asaluyeh and Iraqi soils. These results are confirmed by a MREEs $/$ MREE* N versus HREEs $/$ LREEs $_{N}$ plot (Fig. 5c). The unusual REE pattern of refinery emissions and affected petroleum products resulted not from modifications during transport but rather from the composition of the REE source material (Abbasi et al., 2020). The La/Al ratio of Shiraz dust was 0.00002 , and the crustal ratio was 0.00056 (Johnson et al., 1984). This clearly shows that Shiraz dust mainly originated from natural sources and was less affected by anthropogenic sources encountered along the way or in Shiraz city.

\subsection{PTE concentrations in settled dust particles in shiraz}

Descriptive statistics for the heavy metals $\mathrm{Mo}, \mathrm{Cu}, \mathrm{Pb}, \mathrm{Zn}, \mathrm{Ni}, \mathrm{Co}$, $\mathrm{Mn}, \mathrm{As}, \mathrm{Cd}, \mathrm{Ti}, \mathrm{Al}, \mathrm{Sc}$, and Fe in settled dust samples from Shiraz City are listed in Table 2, including mean, median, mode, standard deviation (std), coefficient of variation (CV), variance, skewness, kurtosis, minimum, maximum, and world-soil average. The results show that $\mathrm{Cu}, \mathrm{Pb}, \mathrm{Zn}, \mathrm{Ni}, \mathrm{Co}, \mathrm{Mn}$, and As concentrations were substantially higher than those of the world-soil average. Generally, the mean levels of $\mathrm{Mo}, \mathrm{Cu}, \mathrm{Pb}, \mathrm{Zn}, \mathrm{Ni}, \mathrm{Co}, \mathrm{Mn}, \mathrm{As}, \mathrm{Cd}, \mathrm{Ti}, \mathrm{Al}, \mathrm{Sc}$, and $\mathrm{Fe}$ in Shiraz dust were 0.24, 47.7, 35.7, 192, 70.3, 19.3, 664, 8.39, 0.65, $537,40,933,11.5$, and $37800 \mathrm{mg} / \mathrm{kg}$, respectively. It is worth mentioning that the concentrations of all elements, except $\mathrm{Pb}, \mathrm{Zn}$, and $\mathrm{Cu}$, were close to the background levels of soil in Iran and Iraq. For example, the Ni concentration in the settled dust was higher than the world-soil average, while this level was close to the background level of $\mathrm{Ni}$ in soils in Iran and Iraq (Abbasi et al., 2018; Abbasi et al., 2019; Esmaili et al., 2014; Rastegari Mehr et al., 2016; Awadh et al., 2015; Al Obaidy et al., 2013). Based on the coefficient of variation, the examined elements could be classified into two groups: $\mathrm{Mo}, \mathrm{Cu}, \mathrm{Pb}, \mathrm{Zn}$, and $\mathrm{Cd}$, with $\mathrm{CV}>0.4$; and those with $\mathrm{CV}<0.4$. Therefore, it seems that the elements $\mathrm{Mo}, \mathrm{Cu}, \mathrm{Pb}, \mathrm{Zn}$, and 
Table 2

Statistical parameters and comparison of heavy metal concentrations $\left(\mathrm{mg} \mathrm{kg}^{-1}\right)$ in settled dust from Shiraz.

\begin{tabular}{|c|c|c|c|c|c|c|c|c|c|c|c|c|c|c|}
\hline & Mo & $\mathrm{Cu}$ & $\mathrm{Pb}$ & $\mathrm{Zn}$ & $\mathrm{Ni}$ & Co & $\mathrm{Mn}$ & As & $\mathrm{Cd}$ & $\mathrm{Ti}$ & $\mathrm{Al}$ & Sc & $\mathrm{Fe}$ & $\mathrm{Mg}$ \\
\hline Mean & 0.24 & 47.67 & 35.71 & 192.86 & 70.27 & 19.33 & 664.00 & 8.39 & 0.65 & 537.33 & 40933.33 & 11.54 & 37800.00 & 22333.33 \\
\hline Median & 0.21 & 38.00 & 22.5 & 145 & 70.00 & 18.00 & 660.00 & 8.00 & 0.52 & 530.00 & 41000.00 & 11.00 & 38000.00 & 22,000 \\
\hline Mode & 0.09 & 38.00 & 18.00 & 110 & 71.00 & 18.00 & 640.00 & 7.80 & 0.42 & 510.00 & 41000.00 & 11.00 & 35000.00 & 23,000 \\
\hline Std. Deviation & 0.18 & 30.71 & 24.79 & 158.72 & 3.20 & 4.70 & 19.57 & 1.57 & 0.31 & 126.18 & 3731.46 & 3.04 & 2274.08 & 723.747 \\
\hline $\mathrm{CV}$ & 0.74 & 0.64 & 0.7 & 0.82 & 0.05 & 0.24 & 0.03 & 0.19 & 0.48 & 0.23 & 0.09 & 0.26 & 0.06 & 23.45 \\
\hline Variance & 0.03 & 943.24 & 614.68 & 25191.21 & 10.21 & 22.10 & 382.86 & 2.46 & 0.10 & 15920.95 & 13923809.52 & 9.24 & 5171428.57 & 523809.524 \\
\hline Skewness & 1.33 & 3.03 & 1.64 & 3.22 & 0.63 & 3.62 & 0.40 & 3.73 & 1.77 & 0.93 & -1.17 & 3.24 & 0.62 & -0.628 \\
\hline Kurtosis & 0.79 & 9.91 & 2.4 & 11.1 & 0.77 & 13.64 & -0.94 & 14.21 & 2.18 & 1.93 & 2.59 & 11.76 & 0.30 & -0.654 \\
\hline Minimum & 0.07 & 30.00 & 17.00 & 100.00 & 65.00 & 16.00 & 640.00 & 7.50 & 0.42 & 370.00 & 31000.00 & 8.70 & 35000.00 & 21,000 \\
\hline Maximum & 0.65 & 150.00 & 100.00 & 720.00 & 77.00 & 36.00 & 700.00 & 14.00 & 1.40 & 860.00 & 46000.00 & 22.00 & 43000.00 & 23,000 \\
\hline World-soil average $^{a}$ & 1.8 & 14 & 25 & 62 & 18 & 6.9 & 418 & 4.7 & 1.1 & 3300 & 71,000 & 9.5 & 35,000 & $500-5000^{e}$ \\
\hline Soil background of Asaluyeh ${ }^{\mathrm{b}}$ & 1.39 & 18.63 & 7.96 & 62.45 & 62 & 10 & 491.5 & 5.55 & 0.21 & 255 & 12,900 & 3.75 & 18,500 & 18,050 \\
\hline Soil background of Isfahan ${ }^{c}$ & - & 30.3 & 37.5 & 120 & 83 & 17.9 & 791.2 & - & 0.42 & - & 68,000 & - & 32,000 & - \\
\hline Soil background of Ahvaz ${ }^{\mathrm{d}}$ & - & 21.39 & 8.01 & 48 & - & 12.45 & - & - & 0.4 & - & 14,800 & - & 18,800 & - \\
\hline
\end{tabular}

a Taylor and McLennan, 1985.

b Abbasi et al., 2018.

c Esmaili et al., 2014.

d Rastegari Mehr et al., 2016.

e Mengel et al., 2001 (500 mg/kg for sandy soils and $5000 \mathrm{mg} / \mathrm{kg}$ for clay soils).

Cd were more influenced by anthropogenic sources (Yongming et al., 2006; Yuan et al., 2014; Abbasi et al., 2017).

Population density, industrial operations, geological setting, climatic conditions, traffic load, and wind patterns can affect the PTE concentrations in dust particles and result in different concentrations in different cities (Abbasi et al., 2020; Keshavarzi et al., 2018). Regardless of natural factors, Table S4 shows that the settled dust samples in the survey city had relatively similar concentrations of $\mathrm{Pb}$ compared to the settled dust particles found in Asaluyeh County. Also, the $\mathrm{Pb}$ concentration in the dust from Shiraz was lower than that of the street dust measured in other cities (Table S4). However, the results showed that the concentrations of elements such as As, Cd, Mn, and Fe in the settled dust were higher than in the street dust. It should be noted that the settled dust used in this study was related to one specific dust storm and thus, the measurements were less affected by the urban setting. The level of $\mathrm{Zn}$ was low but higher than levels in Ottawa and the $\mathrm{Cu}$ level was lower than in other cities. The $\mathrm{Ni}$ and Co concentrations in cities in Iran and Iraq were higher than other regions. Generally, these elements are found in high concentrations in the background soils of Iran and Iraq. These results indicate that the settled dust in Shiraz was more affected by geogenic sources.

\subsection{Pollution level of PTEs in settled dust in shiraz}

The Shapiro-Wilk test indicated that the elements $\mathrm{Co}, \mathrm{Cu}, \mathrm{Zn}$, As, Mo, Cd, and $\mathrm{Pb}$ were non- normally distributed (Table S5) and the relevant statistical methods were used for PTE interpretation. As seen in Table 2, the average concentrations of $\mathrm{Ni}$ and $\mathrm{Cd}$ were higher than average concentrations found in Iran and China, respectively (IDOE, 2014; NEPAC, 1995). However, the amounts of $\mathrm{Pb}, \mathrm{Cd}, \mathrm{Zn}, \mathrm{Cu}$, and Mo found in some stations, including S14, S3, and S5, were higher than the Iranian, Canadian, and Chinese soil quality guideline limits (IDOE, 2014; CCME, 2007 and NEPAC, 1995). However, fine settled dust particles and their PTE content are a potential threat to human health.

A similar result was obtained by analysing the enrichment factor. The results for examined PTEs are shown in Fig. 6 and present the low levels of enrichment beyond the world-soil average value. Fig. 6 indicates that the mean EF contents decreased in the order of $\mathrm{Ni}>\mathrm{Cu}>\mathrm{Zn}>\mathrm{Co}>\mathrm{As}>\mathrm{Mn}>\mathrm{Pb}>\mathrm{Fe}>\mathrm{Cd}>\mathrm{Al}>\mathrm{Ti}>\mathrm{Mo}$. It is clearly shown in Fig. 6 that EF variations were more prominent for $\mathrm{Pb}, \mathrm{Ni}, \mathrm{Cu}$, and $\mathrm{Zn}$. It is worth mentioning that only the elements $\mathrm{Zn}$,

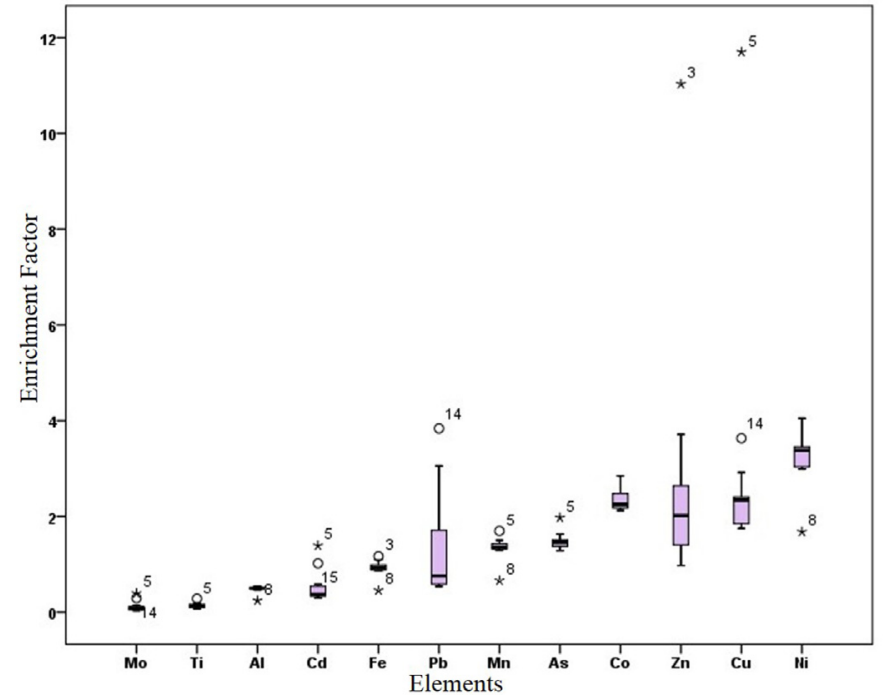

Fig. 6. Box plot of the Enrichment factor (EF) for the studied elements in the dust from Shiraz samples.

$\mathrm{Pb}$, and $\mathrm{Cu}$ had a wide range and/or asymmetric box plots while $\mathrm{Ni}$ and other elements had a low range and a symmetric box plot. In addition, based on Table 2, the variation coefficient values of Mo, $\mathrm{Cu}, \mathrm{Pb}, \mathrm{Zn}$, and $\mathrm{Cd}$ were more than 0.4 , which is indicative of the influence of anthropogenic sources (Yongming et al., 2006; Yuan et al., 2014; Abbasi et al., 2017). Settled dust came from the same soil source and a similar concentration of PTEs from different stations was expected. However, Fig. 6 indicates that the elements $\mathrm{Zn}$, $\mathrm{Pb}, \mathrm{Cu}$, and Mo were enriched for the stations S14, S3, and S5. Copper shows significant enrichment in station S5 and a significant enrichment was observed for the element $\mathrm{Zn}$ in station S3, while Lead was enriched moderately in station S14. These stations were close to areas with high traffic loads (S14 and S3), a bus terminal and car repair shops (S5). This indicates that fine dust particles could have adsorbed PTEs quickly or old dust may have been mixed into samples during initial collection. Previous investigations have shown that vehicle emissions and diesel and fossil fuel combustion are the primary anthropogenic sources of atmospheric contamination (Aminiyan et al., 2018). In general, a deficiency to minimal and moderate enrichment was found for all the elements. 
According to Zhang and Liu (2002), EF values lower than 1.5 indicated that elements originated from natural sources such as weathering of the mother rock and EF values higher than 1.5 showed that elements originated from anthropogenic sources. Also, PTEs with mean EF values more than 10 are believed to originate from human activities (Yongming et al., 2006). Enrichment factors cannot be used alone for PTEs source identification. Therefore, statistical analysis should be carried out to get more accurate results. In this study, a PMF analysis was performed, which was an alternative for source identification and contribution independent of the enrichment factor (Abbasi et al., 2020).

\subsection{Source identification of PTEs in settled dust from shiraz}

In the current study, the PMF model based on IMPROVE program was used for the source appropriation of PTEs in settled dust samples from Shiraz (Fig. 7). The PMF results revealed that two major and one minor sources, include geogenic and anthropogenic (such as industrial activity and exhaust emissions) and marine emissions, were the three possible origins for PTEs. PMF model results indicated that the marine (sea salts) factor have not an important role in PTEs emission. The association of the elements with UnM indicates the contribution of marine (sea salt) sources to the surveyed elements. Therefore, the other two factors are considered for source appropriation of PTEs and the elements divides into two factors: Factor 1) Mo, Cu, Pb, Zn, and Cd, and Factor 2) $\mathrm{Al}, \mathrm{Ti}, \mathrm{Ni}, \mathrm{Cr}, \mathrm{Co}, \mathrm{As}, \mathrm{Mn}, \mathrm{Mg}, \mathrm{Fe}$, and Sc. The first factor mainly originates from exhaust emissions and industrial activities. This group of PTEs had a similar pattern with high concentrations at the sampling points that were near terminals, major roads, and highways with high traffic loads. In addition, the enrichment factors $\mathrm{Zn}$,

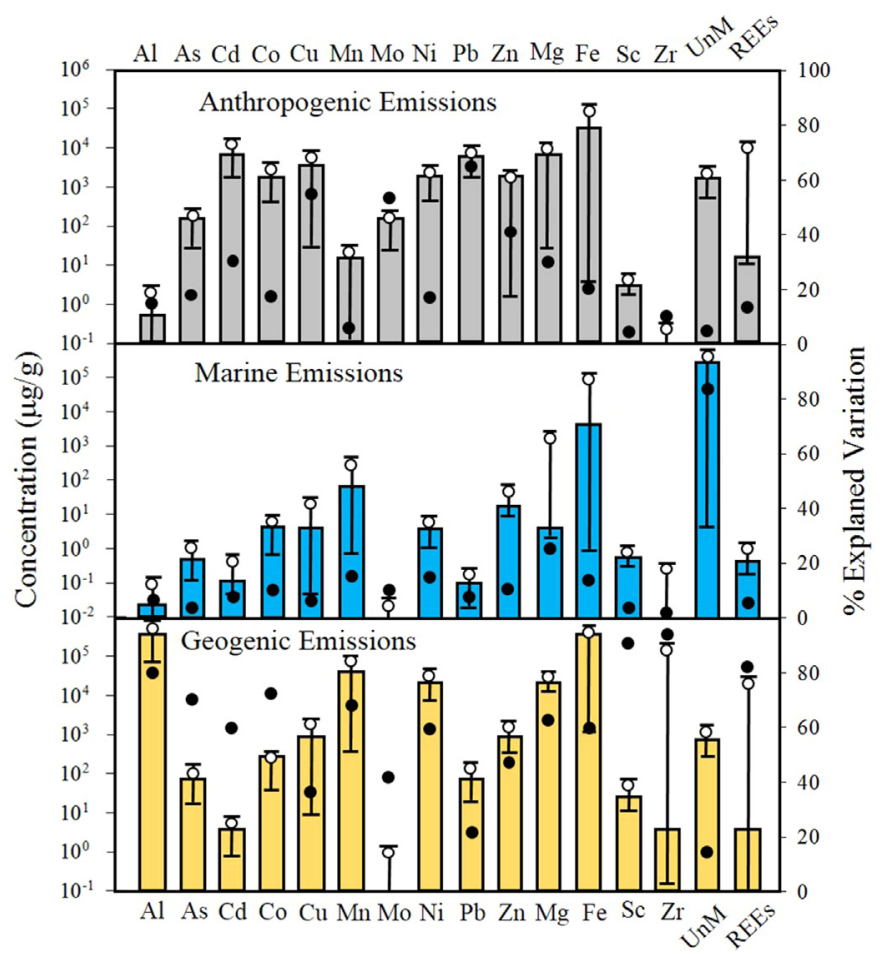

Fig. 7. PMF model based on IMPROVE program for source apportionment of PTEs in Shiraz settled dust. Rectangular columns indicate the concentration of the elements, and black circles are the explained variations, corresponding to the right axis. The \% of that element explained by that factor across the data set. White circles are the average DISP value and the error bars are the maximum and minimum values show the degree of rotational ambiguity.
$\mathrm{Pb}, \mathrm{Cu}, \mathrm{Cd}$, and $\mathrm{Mo}$ in the street dust samples were minimal to significant. As mentioned, PTE concentrations in the settled dust samples showed high variations and the coefficient of variation was more than 0.4. Many investigations pointed out that these PTEs could have originated from industrial and traffic emissions (Abbasi et al., 2020; Zhaoyong et al., 2019; Jadoon et al., 2018; Keshavarzi et al., 2018). In general, $\mathrm{Cu}, \mathrm{Zn}, \mathrm{Pb}$, and $\mathrm{Cd}$ have been observed in high traffic areas (Bem et al., 2003; Sternbeck et al., 2002; Abbasi et al., 2018; Kabata-Pendias and Mukherjee 2007). The element $\mathrm{Cu}$ is used in car brakes to control heat transfer and $\mathrm{Pb}$ is still used in fossil fuels as an antiknock agent (Adachi and Tainosho 2004; Manno et al., 2006; Abbasi et al., 2017). The element Zn can be used in lubricating oils, mechanical abrasions, and tires of automobiles (Arslan 2001; Jiries et al., 2001), and the element Mo is found in the petroleum industries (Abbasi et al., 2018).

The elements in the second factor mainly originated from geogenic sources. These elements ( $\mathrm{Al}, \mathrm{Ti}, \mathrm{Ni}, \mathrm{Cr}, \mathrm{Co}, \mathrm{As}, \mathrm{Mn}, \mathrm{Mg}, \mathrm{Fe}$, and Sc) have a low range and a symmetric box plot of EF values. Moreover, based on the coefficient of variation (lower than 0.4 ), the previously listed elements can be classified into the geogenic elements. These elements are mainly present in the residual fraction which is expressive of the elements' strong associations with the crystalline structures of the soil and thus, their natural source (Belzunce-Segarra et al., 1997; Abbasi et al., 2018). The PMF model indicate the contribution of elements in each source (Fig. 7). Therefore, although the elements $\mathrm{Cu}, \mathrm{Zn}, \mathrm{Mo}, \mathrm{Pb}$, and $\mathrm{Cd}$ are categorized as anthropogenic elements, a high percentage of these elements were provided by geogenic sources. The association of the elements with $\mathrm{Zr}$ and REEs also indicates the attribution of each element in the geogenic sources, although REEs are also slightly released by anthropogenic sources. Eventually, it can be concluded that the settled dust was mostly affected by natural sources and that urban and industrial activities had an impact on them during transport.

\subsection{Ecological and health risk assessment}

The pollution loading index (PLI) was more than 1 in most of the settled dust samples (except S1, S2, S4, S9, S10, S12, and S13) and the potential ecological risk index (RI) showed a low risk for all stations except for S5 which had a moderate risk. The results showed that the mean Er (See Eq. (4)) for the PTEs studied in the dust samples decreased in the following order: $\mathrm{Fe}>\mathrm{Ni}>\mathrm{As}>\mathrm{Cd}>\mathrm{Cu}>\mathrm{Pb}>\mathrm{Zn}$. Er values for the majority of sampling points fell into the low-risk class. However, Er values for copper and cadmium ( $>40$ in S5 station) showed moderate risk. Furthermore, the elements $\mathrm{Cu}, \mathrm{Pb}$, and $\mathrm{Cd}$ were effective factors for increasing the potential ecological risk in the settled dust of Shiraz city. High concentrations of PTEs can affect ecological efficiency (Ogunkunle et al., 2013). Long-term exposure to Cd in dust can cause severe human toxicity leading to kidney disease and serious damage to the internal tissues of children and adults (Bada BS et al., 2012). Furthermore, the ingestion of contaminated dust is the main source of Pb in children's blood (Healy et al., 2008). Therefore, the reduction of PTE concentrations should be considered to avoid the potential danger of these metals in the environment.

Human exposure to PTEs from settled dust in Shiraz via three pathways: ingestion, skin absorption and inhalation for children and adults were investigated. The risk of non-carcinogenic elements for all three pathways showed the following trend: $\mathrm{HQ}_{\text {derm }}<\mathrm{HQ}_{\text {inh }}<\mathrm{HQ}_{\text {ing }}$. The values of $\mathrm{HQ}_{\text {ing }}$ and $\mathrm{HQ}_{\text {inh }}$ for children were higher than for adults, while the skin adsorption pathway for adults was higher than for children. In general, the HQ values of examined elements for all three pathways were lower than 1 and consequently, no harm to humans was expected. It is worth 
mentioning that HI values for children for all three pathways were 4.42-32.98 times higher than those for adults. Therefore, the children were more at risk than the adults. Also, the cancer risk from the elements in dust that settled in Shiraz was low and can generally be ignored. However, these health risk indexes are not enough for a complete evaluation of the risks because the size of the dust particles, suspended dust concentrations, dust minerals, oxidative potentials, and the available concentration of elements in dust particles can affect human health as well.

\subsection{Radionuclides of the settled dust in shiraz}

The activity concentration of the radionuclides ${ }^{7} \mathrm{Be},{ }^{4} \mathrm{~K},{ }^{137} \mathrm{Cs}$, and ${ }^{235} \mathrm{U}$ in the dust that settled in Shiraz were $814,421,14$, and 5.4 $\mathrm{Bq} \mathrm{kg}^{-1}$, respectively (Fig. S2). The abundance of both ${ }^{235} \mathrm{U}$ and ${ }^{238} \mathrm{U}$ in the samples represented the low activity of ${ }^{235} \mathrm{U}$ as compared to ${ }^{238} \mathrm{U}$ ( $115.2 \mathrm{~Bq} \mathrm{~kg}^{-1}$ ), which included $0.75 \%$ and $99.28 \%$ of ${ }^{235} \mathrm{U}$ and ${ }^{238} \mathrm{U}$, respectively. The observed ratio between ${ }^{235} \mathrm{U}$ and ${ }^{238} \mathrm{U}$ in the sample was 0.047 . The activity concentration of ${ }^{4} \mathrm{~K}$ in dust from Shiraz (421 Bq kg-1) was equal to the world average (420 Bq kg${ }^{-1}$ ) and higher than the crustal average $\left(370 \mathrm{~Bq} \mathrm{~kg}{ }^{-1}\right.$ ) (UNSCEAR, 2000). The radioactivity of the soil's primordial radionuclides usually depends on the mineral deposition, the local geological sources they are extracted from, and the processes of transfer (Nguelem et al., 2016). Physical disaggregation and geochemical activity affected the distribution of primordial radionuclides and their components for decay and ${ }^{4} \mathrm{~K}$ in certain geological rocks and soil formations. Plant residues, stones, fertilizers, and animal carcass residues may have led to changes in the activity of ${ }^{4} \mathrm{~K}$ values (Durusoy and Yildirim, 2017).

The activity concentration of ${ }^{137} \mathrm{Cs}$ in the Shiraz dust samples was $14 \mathrm{~Bq} \mathrm{~kg}^{-1}$ and was lower than the world average $\left(51 \mathrm{~Bq} \mathrm{~kg}^{-1}\right.$ ) (UNSCEAR, 2000). The atmospheric fallout of ${ }^{137} \mathrm{Cs}$ is very small and negligible, and if present, is due to eolian resuspension of topsoil particles with adsorbed ${ }^{137} \mathrm{Cs}$ (Matisoff and Whiting, 2012). ${ }^{137} \mathrm{Cs}$ fallout from the 1986 Chernobyl nuclear reactor disaster in some regions of Europe is superimposed on the global signal. Many unintended releases of isotopes of Cs have polluted local areas. In addition, the variations in soil sample behaviour of the ${ }^{137} \mathrm{Cs}$ radionuclides were due to transport via rainfall (Durusoy and Yildirim, 2017). However, Shiraz dust was not wet deposited. This shows that the ${ }^{137}$ Cs likely originated from soil particles with adsorbed ${ }^{137} \mathrm{Cs}$.

The activity concentration of the radionuclides ${ }^{7} \mathrm{Be}$ in the Shiraz dust was $814 \mathrm{~Bq} \mathrm{~kg}^{-1}$. The nuclei of $\mathrm{O}$ and $\mathrm{N}$ and the atmospheric cascade nucleon portion induced by galactic cosmic rays can create ${ }^{7} \mathrm{Be}$ (Dorman, 2004). About $70 \%$ of the ${ }^{7} \mathrm{Be}$ is formed in the stratosphere (Sugihara et al., 2000). The procedure of mixing on the polar front and the subtropical jet as well as the mixing that occurs in large synoptic storms can introduce ${ }^{7} \mathrm{Be}$ to the troposphere from the stratosphere and this event can be caused by cyclones and hurricanes of mid-latitude. Shiraz is located $1585 \mathrm{~m}$ above sea level and the dust event occurred in the spring of 2018 (May 13, 2018). ${ }^{7} \mathrm{Be}$ concentration increases with altitude, despite the large stratospheric reservoir where concentrations may be higher than the upper troposphere (Lal and Baskaran, 2011). Some seasonality of the ${ }^{7} \mathrm{Be}$ concentrations tends to be present in the atmosphere along with the maximum late spring and summer values (Caillet et al., 2001). In late spring and summer, the seasonal increase in ${ }^{7} \mathrm{Be}$ concentration is thought to be caused by enhanced mixing of stratospheric air into the troposphere (El-Hussein et al., 2001).

\section{Conclusion}

According to the results of the current study, it can be concluded that the Shiraz dust event on the May 13, 2018 mainly originated from Saudi Arabia and was affected by Iran and Iraq soils during transport. In general, all of the elements showed deficiency to minimal and moderate enrichment and some elements including copper, zinc, and lead showed a very high significant enrichment in S3, S5, and S14 stations. These stations were close to high load traffic (S14 and S3), a bus terminal and car repair shops (S5). According to the enrichment factor, coefficient variation, and PMF model, $\mathrm{Mo}, \mathrm{Cu}, \mathrm{Pb}, \mathrm{Zn}$, and $\mathrm{Cd}$ mainly originated from exhaust emissions and industrial activities. The activity concentrations of the radionuclides ${ }^{7} \mathrm{Be},{ }^{4} \mathrm{~K},{ }^{137} \mathrm{Cs}$, and ${ }^{235} \mathrm{U}$ in the Shiraz dust were lower than the crustal average. Health risk assessment indices for the elements through all three pathways revealed that the values of $\mathrm{HQ}_{\text {inh }}$ and $\mathrm{HQ}_{\text {ing }}$ for children were higher than adults, while the skin adsorption pathway for adults was higher than for children.

\section{Credit author statement}

Sajjad Abbasi: Writing - original draft, Modeling, Visualization, Conceptualization, Investigation, Review and Editing, Mahrooz Rezaei: Initial Idea, Conceptualization, Review and Editing, Behnam Keshavarzi: Investigation, Monireh Mina: Sampling, Coen Ritsema: Initial Idea, Resource, Analysing, Violette Geissen: Project leader, Initial Idea, Resource, Analysing.

\section{Declaration of competing interest}

The authors declare that they have no known competing financial interests or personal relationships that could have appeared to influence the work reported in this paper.

\section{Acknowledgments}

The authors would like to thank Wageningen Food Safety Research for technical assistance. Also, it was a honor to work with Professor Dr. Maarten Krol who took time to edit our manuscript.

\section{Appendix A. Supplementary data}

Supplementary data to this article can be found online at https://doi.org/10.1016/j.chemosphere.2021.130533.

\section{References}

Abbasi, S., Keshavarzi, B., 2019. Source identification of total petroleum hydrocarbons and polycyclic aromatic hydrocarbons in PM10 and street dust of a hot spot for petrochemical production: Asaluyeh County, Iran. Sustainable cities and society $45,214-230$.

Abbasi, S., Keshavarzi, B., Moore, F., Delshab, H., Soltani, N., Sorooshian, A., 2017. Investigation of microrubbers, microplastics and heavy metals in street dust: a study in Bushehr city, Iran. Environmental earth sciences 76 (23), 798.

Abbasi, S., Keshavarzi, B., Moore, F., Mahmoudi, M.R., 2018. Fractionation, source identification and risk assessment of potentially toxic elements in street dust of the most important center for petrochemical products, Asaluyeh County, Iran. Environmental earth sciences 77 (19), 673.

Abbasi, S., Keshavarzi, B., Moore, F., Shojaei, N., Sorooshian, A., Soltani, N., Delshab, H., 2019. Geochemistry and environmental effects of potentially toxic elements, polycyclic aromatic hydrocarbons and microplastics in coastal sediments of the Persian Gulf. Environmental Earth Sciences 78 (15), 492.

Abbasi, S., Keshavarzi, B., Moore, F., Hopke, P.K., Kelly, F.J., Dominguez, A.O., 2020. Elemental and magnetic analyses, source identification, and oxidative potential of airborne, passive, and street dust particles in Asaluyeh County, Iran. Sci. Total Environ. 707, 136132.

Adachi, K., Tainosho, Y., 2004. Characterization of heavy metal particles embedded in tire dust. Environ. Int. 30 (8), 1009-1017. https://doi.org/10.1016/ j.envint.2004.04.004.

Ahmady-Birgani, H., Mirnejad, H., Feiznia, S., McQueen, K.G., 2015. Mineralogy and geochemistry of atmospheric particulates in western Iran. Atmos. Environ. 119, $262-272$.

Ahmady-Birgani, H., McQueen, K.G., Mirnejad, H., 2018. Characteristics of mineral dust impacting the Persian Gulf. Aeolian Research 30, 11-19. https://doi.org/ 
10.1016/j.aeolia.2017.11.001

Al Obaidy, A.H.M., Al Mashhadi, A.A., 2013. Heavy Metal Contaminations in Urban Soil within Baghdad City (Iraq).

Al-Shakry, A.J., Ali, F.H., Ali, M.M., Al-Rasoul, K.T., 2010. Characterization of quartz and calcite particle size presents in local dust fell on Baghdad on June 2009. Iraqi Journal of Physics 8 (12), 60-64.

Alghamdi, M.A., Almazroui, M., Shamy, M., Redal, M.A., Alkhalaf, A.K., Hussein, M.A., Khoder, M.I., 2015. Characterization and elemental composition of atmospheric aerosol loads during springtime dust storm in western Saudi Arabia. Aerosol and Air Quality Research 15 (2), 440-453.

Aminiyan, M.M., Baalousha, M., Mousavi, R., Aminiyan, F.M., Hosseini, H., Heydariyan, A., 2018. The ecological risk, source identification, and pollution assessment of heavy metals in road dust: a case study in Rafsanjan, SE Iran. Environ. Sci. Pollut. Res. 25 (14), 13382-13395.

Arslan, H., 2001. Heavy metals in street dust in Bursa, Turkey. J. Trace Microprobe Tech. 19 (3), 439-445. https://doi.org/10.1081/TMA-100105058.

Awadh, S.M., Al-Kilabi, J.A., Khaleefah, N.H., 2015. Comparison the geochemical background, threshold and anomaly with pollution indices in the assessment of soil pollution: Al-Hawija, north of Iraq case study. Int. J. Sci. Res. 4 (7), 2357-2363.

Bada Bs, Kurt-Karakus P.B., 2012. Determination of heavy metals in indoor dust from Istanbul, Turkey: estimation of the health risk. Environ. Int. 50, 47-55.

Begum, B.A., Biswas, S.K., Hopke, P.K., Cohen, D.D., 2006. Multi-element analysis and characterization of atmospheric particulate pollution in Dhaka. Aerosol and Air Quality Research 6 (4), 334-359.

Bem, H., Gallorini, M., Rizzio, E., Krzemińska, M., 2003. Comparative studies on the concentrations of some elements in the urban air particulate matter in Lodz City of Poland and in Milan, Italy. Environ. Int. 29 (4), 423-428. https://doi.org/ 10.1016/S0160 -4120(02)00190-3.

Brown, S.G., Eberly, S., Paatero, P., Norris, G.A., 2015. Methods for estimating uncertainty in PMF solutions: examples with ambient air and water quality data and guidance on reporting PMF results. Sci. Total Environ. 518, 626-635.

Caillet, S., Arpagaus, P., Monna, F., Dominik, J., 2001. Factors controlling Be-7 and Pb210 atmospheric deposition as revealed by sampling individual rain events in the region of Geneva, Switzerland. J. Environ. Radioact. 53, 241-256.

Chen, J., Li, G., Yang, J., Rao, W., Lu, H., Balsam, W., Sun, Y., Ji, J., 2007. Nd and Sr isotopic characteristics of Chinese deserts: implications for the provenances of Asian dust. Geochem. Cosmochim. Acta 71 (15), 3904-3914.

Dorman, L., 2004. Cosmic Rays in the Earth's Atmosphere and Underground. Kluwer Academic, Dordrecht.

Durusoy, A., Yildirim, M., 2017. Determination of radioactivity concentrations in soil samples and dose assessment for Rize Province, Turkey. Journal of Radiation Research and Applied Sciences 10 (4), 348-352.

El-Hussein, A., Mohamemed, A., Abd El-Hady, M., Ahmed, A.A., Ali, A.E., Barakat, A., 2001. Diurnal and seasonal variation of short-lived radon progeny concentration and atmospheric temporal variations of Pb-210 and Be-7 in Egypt. Atmos. Environ. 35, 4305-4313.

Engelbrecht, J.P., McDonald, E.V., Gillies, J.A., Jayanty, R.K.M., Casuccio, G., Gertler, A.W., 2009a. Characterizing mineral dusts and other aerosols from the Middle East Part 1: ambient sampling. Inhal. Toxicol. 21, 297-326. https:// doi.org/10.1080/08958370802464273.

Engelbrecht, J.P., McDonald, E.V., Gillies, J.A., Jayanty, R.K.M., Casuccio, G., Gertler, A.W., 2009b. Characterizing mineral dusts and other aerosols from the Middle East - Part 2: grab samples and re-suspensions. Inhal. Toxicol. 21, 327-336. https://doi.org/10.1080/08958370802464299.

Engelbrecht, J., Stenchikov, G.L., Prakash, P.J., Lersch, T., Anisimov, A., Shevchenko, I., 2017. Physical and Chemical Properties of Deposited Airborne Particulates over the Arabian Red Sea Coastal Plain.

Esmaeili, A., Moore, F., Keshavarzi, B., Jaafarzadeh, N., Kermani, M., 2014. A geochemical survey of heavy metals in agricultural and background soils of the Isfahan industrial zone, Iran. Catena 121, 88-98.

Gill, T.E., Zobeck, T.M., Stout, J.E., 2006. Technologies for laboratory generation of dust from geological materials. J. Hazard Mater. 132 (1), 1-13.

Givehchi, R., Arhami, M., Tajrishy, M., 2013. Contribution of the Middle Eastern dust source areas to PM10 levels in urban receptors: case study of Tehran, Iran. Atmos. Environ. 75, 287-295. https://doi.org/10.1016/J.ATMOSENV.2013.04.039 Pergamon.

Godri, K.J., Green, D.C., Fuller, G.W., Dall'sOsto, M., Beddows, D.C., Kelly, F.J., et al., 2010. Particulate oxidative burden associated with firework activity. Environ. Sci. Technol. 44 (21), 8295-8301.

Gope, M., Masto, R.E., George, J., Balachandran, S., 2018. Tracing source, distribution and health risk of potentially harmful elements (PHEs) in street dust of Durgapur, India. Ecotoxicol. Environ. Saf. 154, 280-293.

Goudie, A.S., 2014. Desert dust and human health disorders. Environ. Int. 63, 101-113. https://doi.org/10.1016/J.ENVINT.2013.10.011 Pergamon.

Goudie, A.S., Middleton, N.J., 2006. Desert Dust in the Global System. Springer Verlag, Heidelberg.

Hakanson, L., 1980. An ecological risk index for aquatic pollution control. A sedimentological approach. Water Res. 14 (8), 975-1001.

Healy, M., Harrison, P., Aslam, M., Davis, S., Wilson, C., 2008. Lead sulphide and traditional preparations: routes for ingestion, and solubility and reactions in gastric fuid. J. Clin. Pharm. Therapeut. 7, 169-173.

Hojati, S., Khademi, H., Cano, A.F., Landi, A., 2012. Characteristics of dust deposited along a transect between central Iran and the Zagros Mountains. Catena 88, $27-36$.
Hui, C., Jian, L., Guizhou, W., Guang, Y., Lei, L., 2015. Identification of sand and dust storm source areas in Iran. Journal of Arid Land 7 (5), 567-578. https://doi.org/ 10.1007/s40333-015-0127-8.

Igarashi, Y., Inomata, Y., Aoyama, M., Hirose, K., Takahashi, H., Shinoda, Y., Sugimoto, N., Shimizu, A., Chiba, M., 2009. Possible change in Asian dust source suggested by atmospheric anthropogenic radionuclides during the 2000s. Atmos. Environ. 43 (18), 2971-2980.

Jackson, N.J., Douch, C.J., 1986. Jabal hamra REE-mineralized silexite, hijaz region, kingdom of Saudi Arabia. J. Afr. Earth Sci. 1983 (4), 269-274.

Jadoon, W.A., Khpalwak, W., Chidya, R.C.G., Abdel-Dayem, S.M.M.A., Takeda, K., Makhdoom, M.A., Sakugawa, H., 2018. Evaluation of levels, sources and health hazards of road-dust associated toxic metals in jalalabad and kabul cities, Afghanistan. Arch. Environ. Contam. Toxicol. 74 (1), 32-45. https://doi.org/ 10.1007/s00244-017-0475-9.

Janssen, N.A., Hoek, G., Simic-Lawson, M., Fischer, P., Van Bree, L., Ten Brink, H., Keuken, M., Atkinson, R.W., Anderson, H.R., Brunekreef, B., Cassee, F.R., 2011. Black carbon as an additional indicator of the adverse health effects of airborne particles compared with PM10 and PM2. 5. Environ. Health Perspect. 119 (12), 1691-1699.

Jiries, A.G., Hussein, H.H., Halaseh, Z., 2001. The quality of water and sediments of street runoff in Amman, Jordan. Hydrol. Process. 15 (5), 815-824. https:// doi.org/10.1002/hyp.186.

Jish Prakash, P., Stenchikov, G., Tao, W., Yapici, T., Warsama, B., Engelbrecht, J.P., 2016. Arabian Red Sea coastal soils as potential mineral dust sources. Atmos. Chem. Phys. 16, 11991-12004. https://doi.org/10.5194/acp-16-11991-2016.

Johnson, D.L., et al., 1984. Only the x-ray fluorescence data are given in this report, but the INAA data were circulated to participants in the test. Atmos. Environ. 18 1539.

Kabata-Pendias, A., Mukherjee, A.B., 2007. Trace Elements from Soils to Humans. Springer, Berlin.

Keshavarzi, B., Abbasi, S., Moore, F., Mehravar, S., Sorooshian, A., Soltani, N. Najmeddin, A., 2018. Contamination level, source identification and risk assessment of potentially toxic elements (PTEs) and polycyclic aromatic hydrocarbons (PAHs) in street dust of an important commercial center in Iran. Environ. Manag. 62 (4), 803-818.

Lal, D., Baskaran, M., 2011. Applications of cosmogenicisotopes as atmospheric tracers. In: Baskaran, M. (Ed.), Handbook of Environmental Isotope Geochemistry. Springer, Heidelberg.

Li, L., Chen, J., Chen, Y., Hedding, D.W., Li, T., Li, L., Liu, X., Zeng, F., Wu, W., Zhao, L., $\mathrm{Li}, \mathrm{G} ., 2018$. Uranium isotopic constraints on the provenance of dust on the Chinese loess plateau. Geology 46 (9), 747-750.

Li, X., Yang, K., Han, J., Ying, Q., Hopke, P.K., 2019. Sources of humic-like substances (HULIS) in PM2. 5 in Beijing: receptor modeling approach. Sci. Total Environ. 671, 765-775.

Malm, W.C., Sisler, J.F., Huffman, D., Eldred, R.A., Cahill, T.A., 1994. Spatial and seasonal trends in particle concentration and optical extinction in the United States. J. Geophys. Res.: Atmosphere 99 (D1), 1347-1370.

Manno, E., Varrica, D., Dongarrà, G., 2006. Metal distribution in road dust samples collected in an urban area close to a petrochemical plant at Gela, Sicily. Atmos. Environ. 40 (30), 5929-5941. https://doi.org/10.1016/J.ATMOSENV.2006.05.020.

Matisoff, G., Whiting P. 2012. Measuring soil erosion rates using natural (7 Be, 210 $\mathrm{Pb}$ ) and anthropogenic (137 Cs, 239,240 Pu) radionuclides. In: Handbook of Environmental Isotope Geochemistry. Springer, Berlin, Heidelberg, pp. 487-519.

McTainsh, G.H., Nickling, W.G., Lynch, A.W., 1997. Dust deposition and particle size in Mali, West Africa. Catena 29, 307-322.

Mengel, Konrad, Kirkby, Ernest A., Kosegarten, Harald, Appel, Thomas, 2001. Magnesium. Principles of Plant Nutrition 541-552.

Meyer, C., Du Plessis, J.J.L., Oberholzer, J.W., 1996. Handbook to reduce the exposure of workers to dust. In: Safety in Mines Research Advisory Committee, pp. 1-157. COL 027.

Middleton, N.J., 1986. A geography of dust storms in South-West Asia. J. Climatol. 6, 183-196.

Moaref, S., Sekhavatjou, M.S., Hosseini Alhashemi, A., 2014. Determination of trace elements concentration in wet and dry atmospheric deposition and surface soil in the largest industrial city, southwest of Iran. Int. J. Environ. Res. 8 (2) 335-346.

Najafi, M.S., Khoshakhllagh, F., Zamanzadeh, S.M., Shirazi, M.H., Samadi, M., Hajikh, S., 2013. Characteristics of TSP loads during the Middle East springtime dust storm (MESDS) in western Iran. Arabian Journal of Geosciences. https:// doi.org/10.1007/s12517-013-1086-z.

Nguelem, E.J.M., Ndontchueng, M.M., Motapon, O., 2016. Determination of 226 Ra, $232 \mathrm{Th}, 40 \mathrm{~K}, 235 \mathrm{U}$ and $238 \mathrm{U}$ activity concentration and public dose assessment in soil samples from bauxite core deposits in Western Cameroon. SpringerPlus 5 (1), 1253.

Ogunkunle, C.O., Fatoba, P.O., 2013. Pollution loads and the ecological risk assessment of soil heavy metals around a mega cement factory in southwest Nigeria. Pol. J. Environ. Stud. 22 (2).

Paatero, P., Tapper, U., 1993. Analysis of different modes of factor analysis as least squares fit problems. Chemometr. Intell. Lab. Syst. 18 (2), 183-194. https:// doi.org/10.1016/0169-7439(93)80055-M.

Paatero, P., Eberly, S., Brown, S.G., Norris, G.A., 2014. Methods for estimating uncertainty in factor analytic solutions. Atmos. Meas. Tech. 7, 781-797.

Polissar, A.V., Hopke, P.K., Paatero, P., Malm, W.C., Sisler, J.F., 1998. Atmospheric aerosol over Alaska 2. Elemental composition and sources. J. Geophys. Res. 103, 
19045-19057.

Prego, R., Caetano, M., Vale, C., et al., 2009. Rare earth elements in sediments of the vigo ria, NW iberian Peninsula. Continent. Shelf Res. 7, 896-902.

Rashki, A., Rautenbach, C.J., de, W., Eriksson, P.G., Kaskaoutis, D.G., Gupta, P., 2011. Temporal changes of particulate concentration in the ambient air over the city of Zahedan, Iran. Air Quality, Atmosphere \& Health. https://doi.org/10.1007/ s11869-011-0152-5, 10.1007/s11869-011-0152-5.

Rashki, A., Kaskaoutis, D.G., Rautenbach, C.J., de, W., Eriksson, P.G., Qiang, M., Gupta, P., 2012. Dust storms and their horizontal dust loading in the Sistan region, Iran. Aeolian Research 5, 51-62.

Rashki, A., Eriksson, P.G., Rautenbach, C.J., de, W., Kaskaoutis, D.G., Grote, W., Dykstra, J., 2013. Assessment of chemical and mineralogical characteristics of airborne dust in the Sistan region, Iran. Chemosphere 90 (2), 227-236.

Rastegari Mehr, M., Keshavarzi, B., Moore, F., Sacchi, E., Lahijanzadeh, A.R., Eydivand, S., Rostami, S., 2016. Contamination level and human health hazard assessment of heavy metals and polycyclic aromatic hydrocarbons (PAHs) in street dust deposited in Mahshahr, southwest of Iran. Hum. Ecol. Risk Assess. 22 (8), 1726-1748.

Reff, A., Eberly, S., Bhave, P., 2007. Receptor modeling of ambient particulate matter data using positive matrix factorization: review of existing methods. J. Air Waste Manag. Assoc. 57 (2), 146-154. https://doi.org/10.1080/ 10473289.2007.10465319.

Schauer, J.., Lough, G.C., Shafer, M.M., Christensen, W.F., Arndt, M.F., DeMinter, J.T., Park, J.-S., 2006. Characterization of Metals Emitted from Motor Vehicles. Health Effect Institute.

Selvasekarapandian, S., Manikandan, N.M., Sivakumar, R., Balasubramanian, S., Venkatesan, T. Meenakshisundaram, V., 1999. Gamma radiation dose from radionuclides in soil samples of Udagamandalam (Ooty) in India. Radiat. Protect. Dosim. 82, 225-228.

Shadfan, H., Mashhady, A.S., Dixon, J.B., Hussen, A.A., 1985. Palygorskite from tertiary formations of eastern Saudi Arabia. Clay Miner. 33, 451.

Singer, A., Ganor, E., Dultz, S., Fischer, W., 2003. Dust deposition over the dead sea. J. Arid Environ. 53, 41-59.

Sternbeck, J., Sjödin, A., Andréasson, K., 2002. Metal emissions from road trafc and the influence of resuspension-results from two tunnel studies. Atmos. Environ. 36 (30), 4735-4744. https://doi.org/10.1016/S1352-2310(02)00561-7.

Stone, R., 2015. Saving Iran's great salt lake. Science 349 (6252), 1044-1047. https:// doi.org/10.1126/science.349.6252.1044.

Sugihara, S., Momoshima, N., Maeda, Y., Osaki, S., 2000. Variation of atmospheric 7Be and 210Pb depositions at Fukuoka, Japan. In: 10th International Congress of the International Radiation Protection Association. Hiroshima, Japan 10-19 May 2000 .

Tang, Y., Han, G., Wu, Q., Xu, Z., 2013. Use of rare earth element patterns to trace the provenance of the atmospheric dust near Beijing, China. Environmental earth sciences 68 (3), 871-879.

Taskin, H., Karavus, M.E.L.D.A., Ay, P., Topuzoglu, A.H.M.E.T., Hidiroglu, S. Karahan, G., 2009. Radionuclide concentrations in soil and lifetime cancer risk due to gamma radioactivity in Kirklareli, Turkey. J. Environ. Radioact. 100 (1), 49-53.

Taylor, S.R., McLennan, S.M., 1985. The Continental Crust: its Composition and Evolution. Blackwell, Oxford, p. 312.

Tobia, F.H., 2018. Stable isotope and rare earth element geochemistry of the Baluti carbonates (Upper Triassic), Northern Iraq. Geosci. J. 22 (6), 975-987.

Tufail, M., Akhtar, N., Waqas, N., 2006. Radiat. Meas. 41, 443.

UNSCEAR, 2000. Sources and effects of ionizing radiation. United Nations Scientific Committee on the Effects of Atomic Radiation 1. United Nations, New York.

USEPA, 1996. Soil Screening Guidance: Technical Background Document. EPA/540/ R-95/128. Office of Soild Waste and Emergency Response. U.S. Environmental Protection Agency, Washington DC.

Verougstraete, V., Lison, D., Hotz, P., 2003. Cadmium, lung and prostate cancer: systematic review of recent epidemiological data. J. Toxicol. Environ. Health B Crit. Rev. 6, 227-256.

Vishkaee, F.A., Flamant, C., Cuesta, J., Oolman, L., Flamant, P., Khalesifard, H.R., 2012 Dust transport over Iraq and northwest Iran associated with winter Shamal: a case study. J. Geophys. Res. 117, D03201. https://doi.org/10.1029/2011JD016339. WHO/SDE/OEH/99.14

Yang, X.P., Liu, Y.S., Li, C.Z., et al., 2007. Rare earth elements of Aeolian deposits in Northern China and their implications for determining the provenance of dust storms in Beijing. Geomorphology 4, 365-377.

Yongming, H., Peixuan, D., Junji, C., Posmentier, E.S., 2006. Multivariate analysis of heavy metal contamination in urban dusts of Xi'an, Central China. Sci. Total Environ. 355, 176-186.

Yuan, G.L., Sun, T.H., Han, P., Li, J., Lang, X.X., 2014. Source identification and ecological risk assessment of heavy metals in topsoil using environmental geochemical mapping: typical urban renewal area in Beijing. J. Geochem. Explor. 136, 40-47.

Zhao, W., Balsam, W., Williams, E., Long, X., Ji, J., 2018. Sr-Nd-Hf isotopic fingerprinting of transatlantic dust derived from North Africa. Earth Planet Sci. Lett. 486, 23-31.

Zhaoyong, Z., Mamat, A., Simayi, Z., 2019. Pollution assessment and health risks evaluation of (metalloid) heavy metals in urban street dust of 58 cities in China Environ. Sci. Pollut. Control Ser. 26 (1), 126-140. https://doi.org/10.1007/ s11356-018-3555-0.

Zoljoodi, M., Didevarasl, A., Saadatabadi, A.R., 2013. Dust events in the western parts of Iran and the relationship with drought expansion over the dust-source areas in Iraq and Syria. Atmos. Clim. Sci. 3, 321-336. https://doi.org/10.4236/ acs.2013.33034 